\title{
News and Notices
}

\section{The Japanese Contemptus mundi (1596) of the Bibliotheca Augusta: A Brief Remark on a New Discovery}

\author{
Katja Triplett
}

Center for Modern East Asian Studies, University of Göttingen, Germany triplett@uni-goettingen.de

\begin{abstract}
The duke of Brunswick-Lüneburg, August the Younger (1579-1666), assembled one of the largest collections of books and manuscripts in seventeenth-century Europe at his residence in Wolfenbüttel, creating a world-renowned library that is today known as the Bibliotheca Augusta. In about 1662, the duke purchased an unusual 1596 print in Latin script of a religious work offered to him as Tractatus de contemptu mundi in lingua Japonica. It was included in the ethica and not, as one would expect, in the theologica section of his collection, and this may be one of the reasons why the Jesuit print has not been listed in the currently most complete bibliography of prints of the Japanese Jesuit mission press compiled in 1940 by Johannes Laures, S.J., and later supplemented. Apart from the Augusta print only two other prints seemed to have survived. The article introduces the new discovery and outlines possible reasons for the hitherto relative invisibility of the print.
\end{abstract}

\section{Keywords}

book history - translation - Kirishitan-ban - accommodation - Japan - cultural history - Japanese mission - Imitatio Christi - Thomas à Kempis 
Among the many handwritten notes preserved at the Bibliotheca Augusta, there is one addressed to the duke of Brunswick-Lüneburg, August the Younger. The note, written carefully on a slip of paper, describes an unusual book written in Japanese, but with Roman letters, and containing Latin quotations from the Biblia vulgata. This may have been a commendation for the duke to purchase the book from the unknown writer of the note, which is dated July 3 , 1662. The note's mention of the Biblia vulgata, quoted in Latin but found in the main text of a book in Japanese, must have piqued the interest of the elderly duke. He had not only amassed one of the largest collections of books and manuscripts in seventeenth-century Europe at his residence in Wolfenbüttel, the library now known as the Bibliotheca Augusta, but also worked on revising Martin Luther's German translation of the Bible, in itself an engagement abhorred and strictly prohibited in the Catholic world and, at the same time, not undisputed in contemporaneous Protestant circles. ${ }^{1}$ The duke included the book in his collection in the ethica and not, as one could expect, in the theologica section. This may be one of the reasons why the book is not listed in the currently most complete bibliography of prints of the Japanese Jesuit mission press, a bibliography compiled initially by Johannes Laures, S.J. (1891-1959), at Sophia University in Tokyo in 1940 and subsequently supplemented by others. ${ }^{2}$ The Tractatus de contemptu mundi in lingua Japonica, as the writer of the note accompanying the duke's volume calls it, was printed in 1596 and even the most cursory comparison shows that it is indeed one of three known copies of the Contemptus mundi jenbu: Core Youo itoi, Iesu Christono gočoxequio manabi tatematçuru michiuo voxiyuru qiǒ, hereafter referred to as Contemptus mundi jenbu. Both the standard Laures bibliography and the recently published account by Toyoshima ${ }^{3}$ mention only two copies: one copy held by the Bodleian Library in Oxford ${ }^{4}$ and another kept at the Biblioteca Ambrosiana in Milan,

1 Wolf-Dieter Otte, "Religiöse Schriften," in Sammler, Fürst, Gelehrter: Herzog August zu Braunschweig und Lüneburg 1579-1666, ed. Paul Raabe (Wolfenbüttel: Herzog August Bibliothek, 1979), 193-205. I thank Dr. Matthias Roick (Wolfenbüttel/Göttingen) for this valuable observation.

2 Johannes Laures, Kirishitan bunko: A Manual of Books and Documents on the Early Christian Missions in Japan, 3rd edition (Tokyo: Sophia University, 1957), no. 16 (12), 51-54. An abridged version in Japanese script is listed as no. 32 (27). The Laures Kirishitan Bunko Database is freely accessible online: http://digital-archives.sophia.ac.jp/laures-kirishitan-bunko/ (accessed August 4, 2017).

3 Masayuki Toyoshima, Kirishitan to shuppan [Japanese Christians and the (Mission) Press] (Tokyo: Yagi Shoten, 2013), Appendix.

4 Current shelf no. Arch. B e.42. The most recent complete facsimile of the Bodleian print is found in: Kōji Matsuoka and Takeshi Mitsuhashi, eds., Kontemutsusu munji: Kirishitan shiyrō shūsei (Tokyo: Benseisha, 1979). A reproduction by Adam Matthew Publications can be found 
Italy. ${ }^{5}$ The early fifteenth-century Latin work that formed the basis of the Contemptus mundi jenbu was popular in Europe under the title De imitatione Christi et contemptu omnium vanitatum mundi, more commonly known as Imitatio Christi, a devotional work that was ascribed by many to the French theologian and scholar Jean Gerson (a.k.a. Jean Charlier, $c .1362-1429$ ) but was more likely to have been compiled and authored by Thomas à Kempis (c.1380-1471).

The duke's secretary decided to catalogue the Japanese work, possibly because of its theme of moral education, as an ethica volume. The spine on the seventeenth-century vellum cover says "Tractatus de Contemptu Mundi Japonice sed typis latinis excusus, cura Societ. Jesu. 57.13 Eth." After the death of Duke August the Younger, the strange book seemed to have remained on the shelf in Wolfenbüttel, not inciting much interest. Both as a Catholic missionary book in the library of a staunch Protestant and as a work in a language no one in Europe but the Jesuits themselves could read at the time, the Tractatus de contemptu mundi Japonice faded into obscurity. No one may have touched it for centuries; it is in supreme condition except for some worm damage. ${ }^{6}$ There are also other, more general, factors for the lack of visibility of such books in library catalogues. Quite some time ago, the print was entered, without flaw, into the Bibliotheca Augusta's digital catalogue by the diligent librarians who also duly included a link to the Laures Kirishitan Bunko Database. As Yoshimi Orii so aptly put it in her article on the diffusion of Japanese books from the Jesuit mission press, "the twofold nature of the Kirishitan-ban (Japanese Christian prints) - they are neither fully European nor fully East Asian texts-has proved an obstacle to bibliographical research."7 Also, "because of language and identification issues, there is a possibility that Kirishitan-ban books are

in their series East Meets West: Original Records of Western Traders, Travellers, Missionaries and Diplomats to 1852 (Marlborough, Wiltshire: Adam Matthew Publications, 1998).

5 Former signature: S.Q\#.V.III.30; new signature: S.P. 20. For the facsimile of title pages and last pages of both prints, see Tenri Toshokan [Tenri Library] and Makita Tominaga, eds., Kirishitan-ban no kenkyū: Tominaga sensei koki kinen [The Study of Kirishitan-ban: Festschrift for Professor Tominaga] (Tenri: Tenri Daigaku Shuppanbu, 1973), 265-67, figs. 1-6, Bodleian print; 268, figs. 7-8, Ambrosiana print. A facsimile of the damaged Ambrosiana print combined with pages from the Bodleian print can be found in Arimichi Ebisawa, ed., Kontentsusu munji: Nanō shozai kirishitanban shūroku [Catalogue of Kirishitan Literature in South European Holdings] (Tokyo: Yūshōdō Shoten, 1978).

6 Overall, the worm damage does not limit the readability of the text. For reasons of preservation the book cannot be digitized despite the ambitious digitization program of the Bibliotheca Augusta.

7 Yoshimi Orii, “The Dispersion of Jesuit Books Printed in Japan: Trends in Bibliographical Research and in Intellectual History," Journal of Jesuit Studies 2 (2015): 189-207, here 195, doi: 10.1163/22141332-00202002. 
miscategorized in public libraries and archives in the West." ${ }^{8}$ Indeed, a microfiche of the work in the microfiche facsimile collection Western Books on Asia:Japan, which intends to provide printed materials in Western languages about Japan from the sixteenth century to the advent of World War II, lists the Japanese Jesuit print, ${ }^{9}$ along with several other significant publications in Japanese, but erroneously gives "Ainu" (the language of an ethnic minority in Northern Japan) as the language of the book. The collection consists of thirteen thousand microfiches that are divided into twelve categories, among them "religion" and "philosophy." The categorization of the Kirishitan-ban Contemptus mundijenbu as "philosophy" instead of the more appropriate category of "religion" is perhaps a further obstacle to the study of such prints, a case that proves Orii's point well. The new discovery of another 1596 Contemptus mundi jenbu in the Bibliotheca Augusta was not the result of systematic bibliographical research. Having found this unusual volume in the Wolfenbüttel collection, Dr. Matthias Roick, an expert of European ethica, contacted me, a specialist in Japanese religious history, to identify the book. ${ }^{10}$

The main reason for the extreme rarity of such prints is that, by 1640 , virtually all copies of religious literature produced by the Jesuits in Japan had been destroyed during a period of severe persecution. Those who fled to Macao or to other places took few copies with them or sent these copies to Rome. The urge to repeatedly revise the translations and experiment with both script and technology in the heyday of the Japanese Jesuit mission press is well attested to not only by testimony from Father Diogo de Mesquita $\left(1553^{-1614}\right)^{11}$ and others but also by some of the preserved prints. According to Shigeo Wada's survey, the two known 1596 Contemptus mundi jenbu prints differ in one of the fairly numerous Latin quotes. After a comparison of the two prints, the Ambrosiana print can be surmised to be an emended edition of an earlier one, represented

8 Orii, "Dispersion of Jesuit Books," 197.

9 The microfilm was taken from the Bodleian print.

10 I would like to take the opportunity to express my gratitude to the Lichtenberg-Kolleg, The Göttingen Institute of Advanced Study for providing a stimulating academic environment, and the Bibliotheca Augusta in Wolfenbüttel with its team headed by Prof. Peter Burschel, the Head of Rare Books at the Bodleian Libraries, University of Oxford, Dr. Sarah Wheale and her team, Prof. Yoshitsugu Sawai of Tenri University and the deputy director of Tenri Central Library, Prof. emeritus Gen Miyata and his team including Mr. Jun-ichi Kanzaki for their professional support in researching the Jesuit prints.

11 See quote in a letter from de Mesquita in Diego Pacheco, "Diogo de Mesquita, S.J. and the Jesuit Mission Press," Monumenta Nipponica 26, no. 3-4 (1971): 431-43, here 441-42, doi: 10.2307/2383655; translated from Archivum Romanum Societatis Iesu, Jap. Sin. 36, $27^{\mathrm{v}}$. 
by the Bodleian print. Wada, as reported by Arimichi Ebisawa, notes a passage on page 6 , lines $5^{-7}$ of the Bodleian print that reads:

OCVLVS non videt, nec auris audiuit, nec

in cor hominis ascendit, quae praeparauit Deus ijs, qui diligunt illum. 1. Cor. 2. Manacova mi-

This quotation from Corinthians of the words of the prophet Isaiah (Isaiah 64:4), "eye hath not seen, nor ear heard, neither have entered into the heart of man, the things which God hath prepared for them that love him," is followed by the Japanese word for "eye" (modern: manako) leading into the Japanese translation. The translation, however, does not correspond with the biblical quote. Quite obviously, the translator(s) neglected to insert the correct biblical quote into the text. Interestingly, in the Ambrosiana print, the three mistaken lines appear to have been completely replaced and now read more consistently with the main message of the medieval work:

\section{NON SATVRATVUR OCV-}

lus visu, nec auris auditu impletur. Ecclesia

stes capite primo. Fitono manacoua mi-12

This quote from Ecclesiastes, "the eye is not satisfied with seeing, nor the ear filled with hearing" (Eccles. 1:8), is not found in the Augusta print, which incorporates the unconnected citation from the Corinthians like the Bodleian version. We can understand from a comparison of this passage that the Augusta print must be a copy of the earlier edition.

The citation from the Vulgata within the very first pages of this extraordinary Jesuit book-however erroneous it turned out to be in the context of the Contemptus mundi jenbu after close examination-must have pleased the unknown writer of the note accompanying the Augusta print: He or she recommended it highly and successfully to Duke August.

12 Presumably in order to avoid a disagreeable gap in the emended passage, the word for "human" (fitono, modern: hito no) has been added to the word "eye," indeed managing to fill the line in a meaningful way, as already noted by Arimichi Ebisawa, "Kaisetsu" [Explanation], in Nanō shozai kirishitanban shūroku [Catalogue of Kirishitan Literature in South European Holdings] (Tokyo: Yūshōdō Shoten, 1978), 3-4. 